\title{
EFFECT OF QUERCETIN ADMINISTRATION ON LIPID PROFILE, INFLAMMATORY AND OXIDATIVE STRESS MARKERS IN A RAT MODEL OF PROPYLTHIOURACIL-INDUCED HYPOTHYROIDISM
}

\author{
By
Fatma M. Lebda, Sahar M. El Agaty, Noha N. Lasheen, and Haliema A. El Sherif * \\ Physiology Department, Faculty of Medicine, Ain Shams University \\ Physiology Department, Faculty of Medicine, AlMergib University AlKhums, Libya* \\ Corresponding author: Fatma M. Lebda \\ Email: flebda@yahoo.com
}

\begin{abstract}
Background: Hypothyroidism, a prevalent disorder, has deleterious effects such as dyslipidemia, prominent oxidative stress and coexistent inflammatory state. Quercetin, a flavonoid, has unique biological properties including antioxidant and anti-inflammatory activities, as well as the ability to inhibit lipid peroxidation.

Objectives: This study investigated the possible beneficial effects of quercetin administration on lipid profile, inflammatory and oxidative stress markers in a rat model of propylthiouracil (PTU)-induced hypothyroidism.

Materials and Methods: Forty Five adult female albino rats were allocated randomly and equally into three groups:
Control group, PTU-induced hypothyroid group, and quercetin-treated hypothyroid group. At the end of experimental
period, all rats were subjected to measurement of the following parameters: serum levels of free tri-iodothyronine (T3),
free thyroxine (T4), tumor necrosis factor- $\alpha$ (TNF- $\alpha$ ) and reduced glutathione; and plasma levels of triglycerides (TG),
total cholesterol (TC), high density lipoprotein-cholesterol (HDL-C), low density lipoprotein-cholesterol (LDL-C), as
well as malondialdehyde (MDA). Atherogenic index was also calculated.
\end{abstract}

Results: PTU-induced hypothyroid group exhibited significantly lower levels of free T3 and T4, in addition to increased final body weight and percent of body weight gain, associated with dyslipidemia compared to control group. Treating hypothyroid rats with quercetin did not regain the euthyroid status. However, it significantly reduced final body weight and percent of body weight gain compared to the hypothyroid group. Also, quercetin treatment markedly improved the hypothyroidism-induced dyslipidemia by significantly decreasing TG, TC, LDL-C and atherogenic index, accompanied by increased HDL-C compared to the hypothyroid group, achieving levels comparable to that of controls. Hypothyroid rats also displayed a significantly higher plasma MDA level and serum TNF- $\alpha$ level, compared to control group. Hypothyroid rats treated with quercetin showed significantly reduced plasma MDA and elevated reduced glutathione level in addition to significantly lowered serum TNF- $\alpha$ level, compared to untreated hypothyroid group.

Conclusion: The results of this study indicated a pronounced protective effect of quercetin treatment against the dyslipidemia, oxidative stress and inflammatory status, in a rat model of hypothyroidism, suggesting the use of quercetin as a natural therapeutic agent for relieving hypothyroid complications.

Key words: Hypothyroidism, dyslipidemia, oxidative stress, inflammation. 


\section{INTRODUCTION}

The prevalence of hypothyroidism whether subclinical or overt has been increased recently, being higher in women (Baumgartner et al., 2014 and Giorda et al., 2017). Thyroid hormones have multiple effects acting as an essential regulatory factor in numerous physiological systems including the cardiac and vascular tissue (Danzi and Klein, 2012), the cell antioxidant status (Chakrabarti et al., 2016), and all aspects of fat metabolism (Hall, 2016).

Decreased thyroid hormones secretion greatly increases the plasma concentrations of cholesterol, phospholipids, and triglycerides (Grais and Sowers, 2014). Hypothyroidism is, also, associated with both increased production of free radicals and reduced capacity of the antioxidative defense (Nanda et al., 2008). The hypothyroidisminduced hyperlipidemia and oxidative stress enhance lipid peroxidation, and almost always cause severe atherosclerosis. Moreover, oxidative stress triggers inflammation, a known pathogenic event that is implicated in all stages of atherosclerosis (Libby, 2012).

Thyroid replacement therapy is not approved by guidelines of major endocrine societies partly because of difficult adjustment of T3:T4 ratios, and risk of over-replacement (Hennessey, 2015). Therefore, development of safe dietary supplements or new modes of treatment for hypothyroidism may be of immense importance .

The crucial role of oxidative stress in progression of hypothyroidism suggests the possible therapeutic efficacy of antioxidants in the hypothyroidism. Therefore, much attention has been paid to flavonoids as natural compounds with negligible adverse effects. Quercetin (3, 5, 7, 3', 4'-pentahydroxyflavone), a flavonoid found in fruits and vegetables, has various biological functions including hypolipidemic (Jahan et al., 2018), antiinflammatory, and oxygen radicalscavenging activities (Aguirre et al., 2011).

Quercetin administration was reported to significantly improve lipid profile in carbon tetrachloride-induced hepatotoxicity in rats (Vijayakumar et al., 2018). Additionally, the antioxidant activity of quercetin was found to exert a cardioprotective effect against isoproterenol-induced myocardial oxidative injury (Liu et al., 2012). Furthermore, the anti-inflammatory properties of quercetin have been recorded in different cell types, both in animal and human models (Bureau et al., 2008).

Recently, treatment of diabetic rats with quercetin attenuated cardiac tissue levels of lipid peroxidation, inflammatory markers, namely TNF- $\alpha$, interleukin (IL)$1 \beta$, and IL-6 (Roslan et al., 2017). Moreover, quercetin can attenuate the cyclophosphamide-induced hepatotoxicity by suppressing the oxidative stress, as well as, the inflammatory reaction (Sherif, 2018), and has important neuroprotective actions in hypothyroidism (Baldissarelli et al., 2017). While the role of quercetin is recognized, the available data concerning the possible beneficial effect of quercetin administration in hypothyroidism are scarce. 


\section{MATERIALS AND METHODS}

\section{Experimental Animals:}

The present study was performed on 45 adult female Wistar rats; weighing 150220 g. Rats were purchased from Animal Farm (El-Zyad import office of experimental animals for colleges and research centers, Giza), and maintained in the Medical Ain Shams Research Center Animal House (MASRI), Faculty of Medicine, Ain Shams University. They were kept under standard conditions of boarding at room temperature of 22-25 ${ }^{\circ} \mathrm{C}$, normal light/dark cycle, and free access to food and water- ad libitum, throughout the whole period of the study. Rats were kept in plastic cages (5 rats /cage) (the cage dimensions wos $43.2 \mathrm{x}$ $34.0 \times 25.1 \mathrm{~cm})$ for one week prior to experimental procedures for acclimation. Rats were fed standard rat diet, consisted of $400 \mathrm{~mL}$ milk, $600 \mathrm{~g}$ bread and vegetables in each $\mathrm{Kg}$ - ad libitum. Meals were introduced daily at 8 a.m. The ethical guidelines of Ain Shams University for the care and use of Laboratory animals were adopted. Further, the Ain Shams Faculty of Medicine Ethical Committee approval was obtained.

\section{Drugs and Chemicals:}

Propylthiouracil (PTU) (Sigma Aldrich Company, Cairo) was supplied as powder. It was freshly prepared by dissolving 10 $\mathrm{mg}$ propylthiouracil in $1 \mathrm{~mL}$ normal saline. Quercetin (Sigma Aldrich Company, Cairo) was freshly prepared by dissolving $50 \mathrm{mg}$ quercetin in $1 \mathrm{~mL}$ distilled water, just before injection.

Induction of Hypothyroidism:
Hypothyroidism was induced by intraperitoneal (i.p.) injection of PTU, according to (Baltaci and Belviranli, 2013) with modification. First, PTU was given in a dose of $10 \mathrm{mg} / \mathrm{kg} /$ day, i.p., 6 days/week for 30 days. However, retroorbital blood displayed non-significant changes in free T3 and free T4. Therefore, the PTU administration was continued for another 30 days at a dose of 15 $\mathrm{mg} / \mathrm{kg} /$ day, 6 days/week, i.p. and the withdrawn samples, thereafter, showed a significant decline in free T3 and free T4.

\section{Experimental Protocol:}

Rats were randomly divided into the following equal groups (15 rats in each group). Control Group: Rats received intraperitoneal injection of normal saline (1 mL/Kg/day, 6 days /week); equivalent to that given with propylthiouracil (PTU) till the end of the experimental period and then received distilled water by gavage (1 $\mathrm{mL} / \mathrm{Kg} /$ day, 6 days /week) for the last 20 days of experimental period; equivalent to that given with quercetin, PTU-induced hypothyroid group: Rats in this group were i.p. injected with PTU in a dose of $10 \mathrm{mg} / \mathrm{kg}$, b.w./day, 6 days/week for 30 days, then $15 \mathrm{mg} / \mathrm{Kg} /$ day, 6 days /week, for another 30 days, and continued till the end of the experimental period (80 days) to maintain the hypothyroid status. Quercetin-treated hypothyroid group: Rats in this group received PTU as in group II till the end of the experimental period. After 60 days of PTU injection, quercetin was administrated by gavage in a dose of $50 \mathrm{mg} / \mathrm{kg}$, b.w./day, 6 days/week, for 20 days (Maciel et al., 2016). 


\section{Experimental Procedures:}

On the day of sacrifice, overnight fasted rats, were weighed and anesthetized by i.p. injection of pentobarbitone $(40 \mathrm{mg} / \mathrm{kg}$ b.w.). Blood samples were collected from the abdominal aorta into a plastic tube which was let to stand for 30 minutes, and a heparinized tube. The tubes were centrifuged at $4000 \mathrm{rpm}$ for 15 minutes. The obtained sera and plasma were put in aliquots and stored at $-80^{\circ} \mathrm{C}$ until used for determination of serum levels of free triiodothyronine (T3), free thyroxin (T4), tumor necrosis factor- $\alpha$ (TNF- $\alpha$ ), and reduced glutathione level; and plasma levels of triglycerides, total cholesterol, HDL-cholesterol, LDL-cholesterol as well as malondialdehyde (MDA).

Biochemical analysis: Serum levels of free $\mathbf{T 3}$ and free $\mathrm{T4}$ were determined by using a solid-phase enzyme immunoassay technique for quantitative determination of free triiodothyronine and free thyroxine using kits supplied by XEMA Co., Ltd; Moscow, Russia. Lipid profile was assayed using colorimetric kits supplied by Bio-diagnostic, Egypt. Atherogenic Index was calculated according to (Crook,
2006) as follows: Atherogenic index= (LDL-C+VLDL-C)/HDL-C. [VLDL-C = Triglycerides/5].

Plasma mlondialdehyde (MDA) level was measured by colorimetric kits supplied by Bio-diagnostic, Egypt. Serum level of tumor necrosis factor -alpha (TNF- $\alpha$ ) was performed quantitatively by ELISA technique, using Rat TNF- $\alpha$ ELISA kits, supplied by Biosource International, Inc., California, USA. Reduced glutathione in serum was measured by colorimetric method, using kits supplied by Bio-diagnostic, Egypt. All assays were performed according to the manufacturer's instructions.

\section{Statistical Analysis:}

All results in the present study were expressed as mean $\pm \mathrm{SE}$ of the mean. Statistical Package for the Social Sciences (SPSS, Inc., Chicago, IL, USA) program, version 20.0, was used to compare significance between each of the two groups. One-way ANOVA for difference between means of the different groups was performed in this study. Differences were considered significant when $\mathrm{p} \leq \mathbf{0 . 0 5}$

\section{RESULTS}

Changes in Serum Levels of Thyroid Hormones and in body weight: Serum levels of free T3 and free T4 significantly decreased in hypothyroid rats compared to controls. Quercetin treatment in hypothyroid rats did not correct the reduced free $\mathrm{T} 3$ and $\mathrm{T} 4$ in hypothyroid group. Both T3 and T4 were still significantly lower in quercetin-treated hypothyroid group versus control rats. The initial body weights of the three studied groups were not significantly different.
The final body weight and the percent of body weight gain at the end of the 80 days study period were significantly higher in the hypothyroid group compared to controls. Treating the hypothyroid rats with quercetin for 20 days resulted in a significant reduction in the final body weight, as well as, the percent of body weight gain in quercetin-treated hypothyroid rats versus the hypothyroid group, becoming insignificantly different 
from their corresponding values in the control group (Table 1).

Table (1): Changes in serum levels of free T3 and freeT4 and in body weight in the different studied groups

\begin{tabular}{|c|c|c|c|}
\hline Groups & $\begin{array}{c}\text { Control } \\
\text { group }\end{array}$ & $\begin{array}{c}\text { Hypothyroid } \\
\text { group }\end{array}$ & $\begin{array}{c}\text { Q- Hypothyroid } \\
\text { group }\end{array}$ \\
\hline Free T3 (pmol/L) & $3.8 \pm 0.29$ & $2.85 \pm 0.25^{\mathrm{a}}$ & $2.59 \pm 0.35^{\mathrm{a}}$ \\
\hline Free T4 (pmol/L) & $10.33 \pm 0.88$ & $5.67 \pm 0.5^{\mathrm{a}}$ & $5.58 \pm 0.42^{\mathrm{a}}$ \\
\hline Initial body weight (g) & $246.27 \pm 3.84$ & $253.2 \pm 3.68$ & $243.7 \pm 3.51$ \\
\hline Final body weight (g) & $254.73 \pm 3.34$ & $291 \pm 5.65^{\mathrm{a}}$ & $263 \pm 2.4^{\mathrm{b}}$ \\
\hline Body weight gain \% & $3.7 \pm 1.66$ & $15.02 \pm 1.91^{\mathrm{a}}$ & $8.19 \pm 1.72^{\mathrm{b}}$ \\
\hline
\end{tabular}

Values were mean \pm SEM of 15 rats in each group.

Final body weight: after 80 days.

${ }^{\text {a }}$ Significance from the control group by LSD, at $\mathrm{P} \leq 0.05$.

${ }^{\mathrm{b}}$ Significance from the hypothyroid group by LSD, at $\mathrm{P} \leq 0.05$.

Q-Hypothyroid: Quercetin-treated hypothyroid group.

Changes in Plasma levels of lipid profile and in atherogenic index: The hypothyroid rats exhibited a significant rise of plasma TC, TG and LDL-C levels and a fall in HDL-C level in comparison to control group. Quercetin treatment for 20 days induced a significant reduction in TC, TG and LDL-C and elevation in HDL-C in quercetin-treated hypothyroid rats versus hypothyroid group. In comparison to the control rats, plasma levels of TG and LDL-C were insignificantly different in quercetintreated hypothyroid, whereas TC was significantly lowered and HDL-C was significantly increased. Concerning atherogenic index, it was significantly elevated in hypothyroid group compared to controls. Quercetin treatment significantly decreased the atherogenic index in quercetin-treated hypothyroid group compared to the hypothyroid rats, achieving a level equivalent to that of the controls (Table 2).

Table (2): Lipid profile and atherogenic index (AI) in the different studied groups

\begin{tabular}{|c|c|c|c|}
\hline Groups & $\begin{array}{c}\text { Control } \\
\text { group }\end{array}$ & $\begin{array}{c}\text { Hypothyroid } \\
\text { group }\end{array}$ & $\begin{array}{c}\text { Q- Hypothyroid } \\
\text { group }\end{array}$ \\
\hline TG (mg/dL) & $136.17 \pm 14.1$ & $277.18 \pm 13.39^{\mathrm{a}}$ & $155.06 \pm 11.94^{\mathrm{b}}$ \\
\hline TC (mg/dL) & $47.18 \pm 3.31$ & $73.53 \pm 2.64^{\mathrm{a}}$ & $35.34 \pm 1.87^{\mathrm{a}, \mathrm{b}}$ \\
\hline LDL-C (mg/dL) & $20.99 \pm 0.9$ & $61.28 \pm 2.95^{\mathrm{a}}$ & $20.77 \pm 1.53^{\mathrm{b}}$ \\
\hline HDL-C (mg/dL) & $40.84 \pm 1.81$ & $27.16 \pm 1.56^{\mathrm{a}}$ & $56.88 \pm 5.08^{\mathrm{a}, \mathrm{b}}$ \\
\hline Atherogenic index & $1.21 \pm 0.1$ & $4.5 \pm 0.27^{\mathrm{a}}$ & $1.13 \pm 0.12^{\mathrm{b}}$ \\
\hline
\end{tabular}

Values were Mean \pm SEM of 15 rats in each group.

${ }^{a}$ Significance from the control group by LSD, at $\mathrm{P} \leq 0.05$

${ }^{\mathrm{b}}$ Significance from the hypothyroid group by $\mathrm{LSD}$, at $\mathrm{P} \leq 0.05$

Q-Hypothyroid: Quercetin-treated hypothyroid group. 
Changes in Oxidative Stress and Inflammatory Markers: Plasma MDA and TNF- $\alpha$ levels were significantly elevated in the hypothyroid group compared to control rats. Quercetin treatment significantly lowered plasma MDA and TNF- $\alpha$ levels in quercetintreated hypothyroid group compared to the hypothyroid rats, both attaining levels comparable to that of the control group. Although serum level of reduced glutathione insignificantly changed in the hypothyroid group compared to control rats. It accomplished a significant higher level in quercetin-treated hypothyroid group when compared to both hypothyroid and control rats (Figure 1).

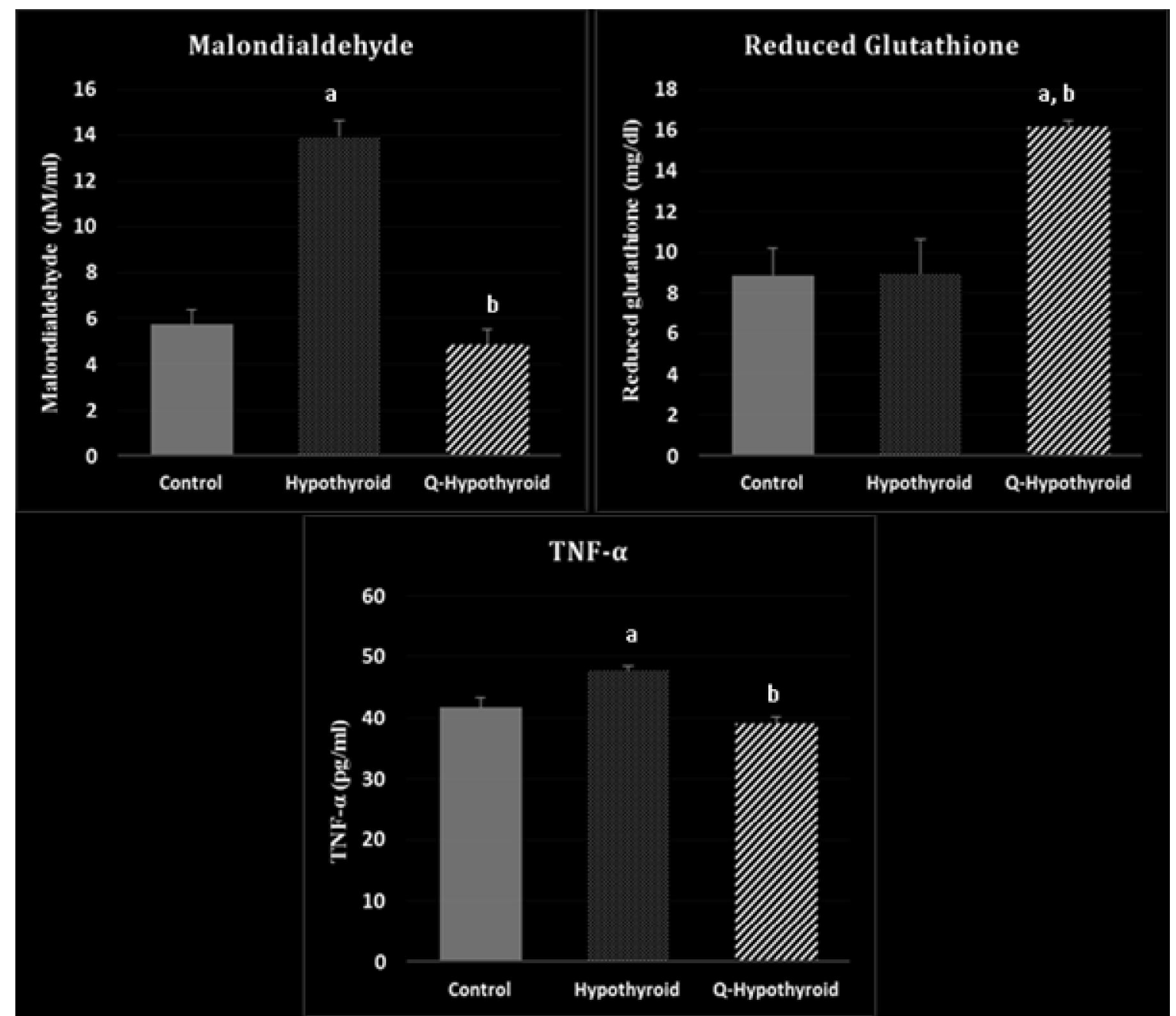

Figure (1): Changes in plasma malondialdehyde level, serum reduced glutathione level, and serum tumor necrosis factor-alfa (TNF- $\alpha)$ level in the different studied groups

a: Significance from the control group by LSD, at $\mathrm{P} \leq 0.05$

b: Significance from the hypothyroid group by LSD, at $\mathrm{P} \leq 0.05$

Q-Hypothyroid: Quercetin-treated hypothyroid group. 


\section{DISCUSSION}

The purpose of this study was to determine the potential protective effects of quercetin on the changes in lipid profile, oxidant/antioxidant balance and inflammatory status in a rat model of propylthiouracil-induced hypothyroidism. The current work revealed that quercetin supplementation $(50 \mathrm{mg} / \mathrm{kg}$, b.w./day for 20 days) decreased body weight gain, improved the dyslipidemia, and attenuated the oxidative stress and proinflammatory biomarkers.

In propylthiouracil-induced hypothyroid rats, serum free $\mathrm{T} 3$ and free T4 significantly decreased, associated with an increase in the final body weight and the percent of body weight gain compared to control group. Treating hypothyroid rats with quercetin did not restore the reduced levels of free T3 and T4 that were still significantly lower than the control values. The inability of quercetin to reverse the decrease in $\mathrm{T} 3$ and $\mathrm{T} 4$ in hypothyroid rats is in accord with the report of (Giuliani et al., 2008) that showed that quercetin inhibits thyroid-cell growth and iodide uptake, associated with down-regulation of sodium/iodide symporter gene expression, in a rat thyroid cell line. In 2014, Giuliani and his coworkers demonstrated a significantly decreased radioiodine uptake in the Sprague-Dawley rat after 14 days of quercetin treatment, confirming that quercetin can act as a thyroid disruptor. According to the aforementioned reports, the inability of quercetin to improve the reduced thyroid hormones, in the present study, could be related to its inhibitory effect on thyroid hormone synthesis. Moreover, the long duration of propylthiouracil supplementation days), herein, might induce marked thyroid tissue damage that could explain such failure. This assumption awaits further investigations.

Nevertheless, this assumption is opposed by other study demonstrated that pretreatment especially with higher dosages of curcumin and quercetin, effectively kept the serum thyroid hormone levels near the normal range, in a rat model of thyroid dysfunction (Nabavi et al., 2011). Recently, (Chen et al., 2017) suggested that collectively, lipoic acid, resveratrol and quercetin are cardio protective and have the ability to restore thyroid hormone levels, in patients with metabolic syndrome induced by thyroid dysfunction. This controversy with the current results of thyroid hormones might be due to the administration of other substances with quercetin, potentiating its effect .

It is noteworthy in this study that in spite of non-restoring the normal level of thyroid hormones, quercetin treatment significantly suppressed the increase in body weight and percent of body weight gain in hypothyroid rats, reaching levels insignificantly different from the control values. This finding is in line with the results of previous studies in different experimental models; quercetin supplementation reduced high fat dietinduced body weight gain in mice (Dong et al., 2014a and Ruiz et al., 2015). Further, administration of both polyphenols; trans-resveratrol and quercetin, together prevented body weight gain and reduced serum insulin levels, in rats, fed a high-fat sucrose diet (Etxeberria et al., 2015). 
Thyroid hormone is very potent in lowering serum cholesterol and TG in animal models and human clinical studies, via regulation of the gene expression related to lipid metabolism as reviewed by (Jin and Teng, 2014). Earlier studies attributed these findings to the ability of thyroid hormone to normalize the increased intestinal absorption of cholesterol and to strongly stimulate hepatic secretion of cholesterol in hypophysectomized rats (G? Iman et al., 2008).

In the present study, rats with hypothyroidism induced by propylthiouracil exhibited a significant rise of plasma levels of TC, TG, and LDL$\mathrm{C}$ and as well atherogenic index, in contrast to a reduction in plasma HDL-C level compared to control group. This is in agreement with the results of (Shashi and Sharma, 2012) that showed that hypothyroidism is associated with an atherogenic lipid and lipoprotein profile. Further, (Khan et al., 2014) and (Sangeeta et al., 2016) observed elevated levels of TC, TG, LDL-C, VLDL-C, TC/HDL ratio, and significantly low levels of HDL$\mathrm{C}$ in hypothyroid patients compared to control group .

Quercetin supplementation, herein, in hypothyroid rats improved the hypothyroidism-induced dyslipidemia, characterized by significant reduction in plasma levels of TC, TG and LDL-C, and atherogenic index, in addition to increased HDL-C, compared to hypothyroid group. In support, the hypolipidemic effect of quercetin has been underscored in dyslipidemic patients (Talirevic and Jelena, 2012), in a rat model of polycystic ovarian syndrome (Jahan et al., 2018), and in carbon tetrachloride-induced hepatotoxicity in rats (Vijayakumar et al., 2018). Moreover, quercetin supplementation displayed a decrease in TG and atherogenic index in rats fed high fat diet (Grzelak-Błaszczyk et al., 2018 and Ting et al., 2018).

On the contrary to the results encountered, herein, previous studies revealed non-significant effect for quercetin supplementation on lipid profile in healthy (Askari et al., 2013) and in obese subjects (Brüll et al., 2015). Such discrepancy could be related to the variation in the study population, duration and/or dose of administration of quercetin used in the previous studies and in the present study .

It is noteworthy in the current study that after treatment with quercetin, TC reached a level even less than that in the control rats, while HDL-C level becomes more than the control value. In addition, the elevated values of TG, LDL-C and atherogenic index in hypothyroid rats, are reversed by quercetin treatment, becoming insignificantly different from the control values. These results had confirmed that quercetin has the potential to correct the dyslipidemic changes that associate the hypothyroidism, returning them to levels comparable to those of the controls.

Previously, the lipid lowering effect of quercetin was assumed to be attributed to the ability of quercetin to regulate lipid catabolism and/or anabolism (Yan et al., 2015). Quercetin was found to upregulate the expression of LDL- receptors in hepatocellular carcinoma cells (Moon et al., 2012), and in human hepatocyte culture (Mbikay et al., 2014) which, in turn, promotes the clearance of the 
circulating LDL-C. Moreover, quercetin was reported to decrease hepatic lipogenesis by reducing the mRNA expression of the enzymes involved in hepatic fatty acid synthesis (Ismail et al., 2014). Recently, the dyslipidemia pattern presented in the subclinical hypothyroid patients was assumed to be induced by the increase in body weight (Chen et al., 2017). Taken together, the correction of the dyslipidemic changes in quercetintreated hypothyroid rats, in the present study, might be attributed to the potential role of quercetin in regulating lipid metabolism or to its ability to ameliorate the hypothyroidism induced body weight gain .

There is essential concern in the role of oxidative stress in the pathogenesis of hypothyroidism. A prospective, nonrandomized study confirmed increased oxidative stress as a consequence of both increased free radical generation and diminished antioxidants in hypothyroid patients (Carmeli et al., 2008). In the present study, propylthiouracil-induced hypothyroidism is associated with an elevation in MDA, along with nonsignificant changes in glutathione compared to controls, suggesting enhanced lipid peroxidation in rats with induced hypothyroidism. These results agree with the previously reported increase in the plasma levels of MDA, and myeloperoxidase activity in patients with overt hypothyroidism (Erdamar et al., 2008). Later, (Chakrabarti et al., 2016) demonstrated a high MDA level in naive primary hypothyroid patients.

The increased oxidant state in hypothyroid rats, as shown by the increased MDA; biomarker of lipid peroxidation, observed in this study, may be attributed to the hypothyroidism, or to the dyslipidemia or both. In support,(Santi et al., 2012) showed that thyroid dysfunction influences lipid metabolism and consequently oxidant/antioxidant status in patients with subclinical hypothyroidism, suggesting that secondary hypercholesterolemia to thyroid dysfunction and not hypothyroidism per se appears to be associated with oxidative stress in subclinical hypothyroidism. More recently, oxidative stress was found to be increased in subclinical hypothyroidism due to elevated plasma lipids induced by low thyroid function (Chen et al., 2017).

The potential anti-oxidant action of quercetin had been reported by (Olayinka et al., 2015). Treating hypothyroid rats with quercetin in the current work was shown to suppress lipid peroxidation and enhance antioxidant capacity, characterized by a significant reduction in MDA compared to hypothyroid rats, attaining a level comparable to that of the controls, together with a rise in glutathione compared to both hypothyroid and control rats. With this regard, these findings are in agreement with the results of previous studies reported that early administration of optimal dose of quercetin may ameliorate brain damage and provide neuroprotection in rat model of subarachnoid hemorrhage, potentially by enhancing the activity of endogenous antioxidant enzymes and inhibiting lipid peroxidation (Dong et al., 2014b). Recently, a marked decrease in oxidative stress, inflammation and apoptosis levels had been observed in hearts of diabetic rats received quercetin, orally for 28 days (Roslan et al., 2017). 
The proved antioxidant action of quercetin may be, at least in part, attributed to restoring the normal level of lipids shown in this study, as secondary hypercholesterolemia to thyroid dysfunction (Santi et al., 2012), and increased plasma lipids in subclinical hypothyroidism (Chen et al., 2017) were claimed to enhance oxidative stress .

On the other hand, oxidative stress was previously reported to influence lipid metabolism and induce dyslipidemia via enhancing insulin resistance (Tangvarasittichai, 2015). Earlier, it had been suggested that the coexistence of oxidative stress and insulin resistance in hypothyroidism play an important role in the pathogenesis of the associated dyslipidemic changes (Santi et al., 2010 and Tagami et al., 2010). Accordingly, the antioxidant activity of quercetin, observed in the present study, could explain the correction of the dyslipidemia in quercetin-treated hypothyroid rats. The aforementioned data speculate interplay between oxidative stress and dyslipidemia. This raises essential concern about the role of oxidative stress in the pathogenesis of dyslipidemia, and/or the ability of dyslipidemia to induce the oxidative stress, but it is still a debate topic.

Regarding the measured proinflammatory biomarker; $\mathrm{TNF}-\alpha$, it was significantly elevated in hypothyroid rats compared to controls. This observation is in concert with the study of (Iams et al., 2015) who found a statistically significant increase in serum TNF- $\alpha$ in patients with lenalidomide-induced hypothyroidism. Recently, (Gong et al., 2018) reported significantly higher levels of TSH, TNF- $\alpha, \quad$ TC and LDL-C, in subclinical hypothyroid rats. Also, (Zhou et al., 2018) observed alteration in NO, IL-6, and TNF$\alpha$ levels, associated with changes in nitric oxide synthase activity and expression, in radioactive iodine-induced hypothyroidism in rats .

The findings of the present study suggested that administration of quercetin may provide protection in hypothyroid rats, partially, by inhibiting the associated inflammatory process, as shown by decreasing the pro-inflammatory marker, TNF- $\alpha$ compared to hypothyroid rats, reaching a level equivalent to that of the controls. Previously, (Bureau et al., 2008) recorded a marked reduction in the lipopolysaccharide-induced mRNA expression of both IL- $1 \alpha$, and TNF- $\alpha$ in glial cells by treatments with resveratrol or quercetin.

In addition, the study of (Milenković et al., 2010) suggested that quercetin ameliorates experimental autoimmune myocarditis, at least in part, by interfering with the production of proinflammatory; TNF- $\alpha$ and IL-17, and/or antiinflammatory; IL-10 and cytokines. Later on, quercetin was reported to suppress inflammation by inhibiting nitric oxide release, a critical mediator of inflammatory response, via downregulating iNOS and COX-2 expression (Choi et al., 2012). Also, quercetin was found able to ameliorate leptin-induced inflammation in human umbilical vein endothelial cells by reducing NF-kB activation and partially suppressing TNFa secretion (Indra et al. 2013). Moreover, quercetin had alleviating effects on viral inflammation based on inhibition of $\mathrm{NO}$, IL-6, TNF- $\alpha$, chemokines, and growth 
factors in macrophages (Kim and Park, 2016).

\section{CONCLUSION}

Quercetin administration to hypothyroid rats was not only able to correct the dyslipidemic changes induced by hypothyroidism, but also it provided the quercetin-treated hypothyroid rats with a less atherogenic lipid profile, proved by the significant lower levels of total cholesterol along with higher levels of HDL-C, in comparison to the control group. Although, such remarkable lipid lowering effect of quercetin was not paralleled with correction of the thyroid hormones levels, it was accompanied by amelioration of the hypothyroidism induced weight gain, oxidative stress, and inflammation. The antioxidant property of quercetin together with the alleviation of weight gain might contribute to its lipid lowering effect in hypothyroidism. These data suggest quercetin as a therapeutic agent with a potential protective impact against hypothyroid complications.

\section{REFERENCES}

1. Aguirre, L., Arias, N., Macarulla, M.T., Gracia, A. and Portillo, M.P. (2011): Beneficial effects of quercetin on obesity and diabetes. Open Nutraceuticals J., 4: 189-198.

2. Askari, G., Hajishafiee, M., Ghiasvand, R., Hariri, M., Darvishi, L., Ghassemi, S. and Hovsepian, V. (2013): Quercetin and vitamin $\mathrm{C}$ supplementation: effects on lipid profile and muscle damage in male athletes. Int $\mathrm{J}$ Prev Med., 4(Suppl 1): S58.

3. Baldissarelli, J., Santi, A., Schmatz, R., Abdalla, FH., Cardoso, A.M., Martins, C.C., Dias, G.R., Calgaroto, N.S., Pelinson, L.P., Reichert, K.P., Loro, V.L., Morsch, V.M. and Schetinger, M.R. (2017): Hypothyroidism Enhanced Ectonucleotidases and Acetylcholinesterase Activities in Rat Synaptosomes can be prevented by the
Naturally Occurring Polyphenol Quercetin. Cell Mol Neurobiol., 37(1):53-63.

4. Baltaci, K.A. and Belviranli, M. (2013): Serum levels of calcium, selenium, magnesium, phosphorus, chromium, copper and iron-their relation to zinc in rats with induced hypothyroidism. Acta Clin Croat., 52(2): 151156.

5. Baumgartner, C., Blum, M.R. and Rodondi, N. (2014): Subclinical hypothyroidism: summary of evidence in 2014. Swiss Med Wkly., 144:w14058.

6. Brüll, V., Burak, C., Stoffel-Wagner, B., Wolffram, S., Nickenig, G., Müller, C. and Zimmermann, B. F. (2015): Effects of a quercetin-rich onion skin extract on $24 \mathrm{~h}$ ambulatory blood pressure and endothelial function in overweight-to-obese patients with (pre-) hypertension: a randomised doubleblinded placebo-controlled cross-over trial $\mathrm{Br}$ Nutr., 114(8):1263-1277.

7. Bureau, G., Longpré, F. and Martinoli, M.G. (2008): Resveratrol and quercetin, two natural polyphenols, reduce apoptotic neuronal cell death induced by neuroinflammation. J Neurosci Res., 86(2): 403-410.

8. Carmeli E., Bachar A., Barchad S., Morad M. and Merrick J. (2008): Antioxidant status in the serum of persons with intellectual disability and hypothyroidism: a pilot study. Res Dev Disabil., 29(5):431-438.

9. Chakrabarti, S.K., Ghosh, S., Banerjee, S., Mukherjee, S. and Chowdhury, S. (2016): Oxidative stress in hypothyroid patients and the role of antioxidant supplementation. Indian $\mathrm{J}$ Endocrinol Metab., 20 (5): 674-678.

10. Chen, Y., Zhou, Z., Li, X.X. and Wang, T. (2017): Research on the protective effects of antioxidants on metabolic syndrome induced by thyroid dysfunction. Eur Rev Med Pharmacol Sci., 21:2489-2498.

11. Choi, S.J., Tai, B.H., Cuong, N.M., Kim, Y.H. and Jang, H.D. (2012): Antioxidative and anti-inflammatory effect of quercetin and its glycosides isolated from mampat (Cratoxylum formosum). Food Sci Biotechnol., 21(2): 587-595. 


\section{FATMA M. LEBDA et al.}

12. Crook, M.A. (2006): Plasma lipids and lipoproteins. In: Clinical Chemistry and Metabolic Medicine, $7^{\text {th }}$ edition, pp. 198-213, Edwarld Arnold publishers Ltd, London, United Kingdom.

13. Danzi, S. and Klein, I. (2012): Thyroid hormone and the cardiovascular system. Med Clin North Am., 96(2):257-68.

14. Dong, J., Zhang, X., Zhang, L., Bian, H. X., Xu, N., Bao, B. and Liu, J. (2014a): Quercetin reduces obesity-associated adipose tissue macrophage infiltration and inflammation in mice: a mechanism including AMPK $\alpha 1 / S I R T 1 . J$ Lipid Res., 363-74.

15. Dong, Y.S., Wang, J.L., Feng, D.Y., Qin, H.Z., Wen, H., Yin, Z. M. and Li, C. (2014b): Protective effect of quercetin against oxidative stress and brain edema in an experimental rat model of subarachnoid hemorrhage. Int J Med Sci., 11(3): 282-90.

16. Erdamar, H., Demirci, H., Yaman, H., Erbil, M.K., Yakar, T., Sancak, B. and Yetkin, I. (2008): The effect of hypothyroidism, hyperthyroidism, and their treatment on parameters of oxidative stress and antioxidant status. Clin Chem Lab Med., 46(7): 1004-1010.

17. Etxeberria, U., Arias, N., Boqué, N., Macarulla, M.T., Portillo, M.P., Mart?nez, J.A. and Milagro, F.I. (2015): Reshaping faecal gut microbiota composition by the intake of trans-resveratrol and quercetin in high-fat sucrose diet-fed rats. J Nutr Biochem., 26(6): 651-660.

18. G?Iman, C., Bonde, Y., Matasconi, M., Angelin, B. and Rudling, M. (2008): Dramatically increased intestinal absorption of cholesterol following hypophysectomy is normalized by thyroid hormone. Gastroenterology., 134(4): 1127-1136.

19. Giorda, C.B., Carnà, P., Romeo, F., Costa, G., Tartaglino, B. and Gnavi, R. (2017): Prevalence, incidence, and associated comorbidities of treated hypothyroidisman update from a European population. Eur J Endocrinol., 176(5):533-542.

20. Giuliani, C., Bucci, I., Di Santo, S., Rossi, C., Grassadonia, A., Piantelli, M. and
Napolitano, G. (2014): The flavonoid quercetin inhibits thyroid-restricted genes expression and thyroid function. Food Chem Toxicol., 66: 23-29.

21. Giuliani, C., Noguchi, Y., Harii, N., Napolitano, G., Tatone, D., Bucci I., Piantelli, M., Monaco, F. and Kohn, L.D. (2008): The Flavonoid quercetin regulates growth and gene expression in rat FRTL-5 thyroid cells. Endocrinology., 149(1):84-92.

22. Gong, N., Gao, C., Chen, X., Wang, Y. and Tian, L. (2018): Adipokine expression and endothelial function in subclinical hypothyroidism rats. Endocr Connect., 7(2): 295-304.

23. Grais, I.M. and Sowers, J.R. (2014): Thyroid and the heart. Am J Med., 127(8):691-8.

24. Grzelak-Błaszczyk, K., Milala, J., Kosmala, M., Kołodziejczyk, K., Sójka, M., Czarnecki, A. and Jurgoński, A. (2018): Onion quercetin monoglycosides alter microbial activity and increase antioxidant capacity. J Nutr Biochem., 56: 81-88.

25. Hall, J.E. (2016): Thyroid metabolic hormones. In: Textbook of Medical Physiology, 13th edition. J.E., Hali (ed.), pp. 956. Elsevier, Philadelphia, USA.

26. Hennessey, J.V . (2015): Historical and current presective in the use of thyroid extracts for the treatment of hypothyroidism. Endocr Pract., 21(10):1161-70.

27. Iams, W.T, Hames, M.L., Tsai, J.P., Dahlman, K.B., Talbott, M.S., Richards, K.L. and Reddy, N.M. (2015): Thyroid dysfunction in patients with diffuse large B-cell lymphoma receiving lenalidomide is mediated by TNF- $\alpha$. Exp Hematol., 43(2): 74-78.

28. Indra, M.R., Karyono, S., Ratnawati, R. and Malik, S.G. (2013): Quercetin suppresses inflammation by reducing ERK1/2 phosphorylation and NF kappa B activation in leptin-induced human umbilical vein endothelial cells (HUVECs). BMC Res Notes., 6(1): 275.

29. Ismail, H. A., Hamza, R.Z. and El-Shenawy, N. S. (2014): Potential protective effects of blackberry and quercetin on sodium fluorideinduced impaired hepato-renal biomarkers, sex 
hormones and hematotoxicity in male rats. J Appl Life Sci Intern., 1(1): 1-16.

30. Jahan, S., Abid, A., Khalid, S., Afsar, T., Shaheen, G., Almajwal, A. and Razak, S. (2018): Therapeutic potentials of Quercetin in management of polycystic ovarian syndrome using Letrozole induced rat model: a histological and a biochemical study. J Ovarian Res., 11(1): 26.

31. Jin, T. and Teng, X. (2014): Update on lipid metabolism and thyroid disorders. J Endocrinol Diabetes Obes., 2(3): 1043.

32. Khan F.A., Patil S.K.B., Thakur A.S., Khan M.F. and Murugan K. (2014): Lipid Profile in Thyroid Dysfunction: A Study on Patients of Bastar. J Clin Anal Med., 5(1): 12-14.

33. Kim, Y.J. and Park, W. (2016): Anti-Inflammatory Effect of Quercetin on RAW 264.7 Mouse Macrophages Induced with Polyinosinic-Polycytidylic Acid. Molecules., 21(4): 450.

34. Libby, P. (2012): Inflammation in atherosclerosis. Arterioscler Thromb Vasc Biol., 32:2045-2051.

35. Liu, H., Zhang, L. and Lu, S. (2012): Evaluation of antioxidant and immunity activities of quercetin in isoproterenol-treated rats. Molecules., 17(4): 4281-4291.

36. Maciel, R.M., Carvalho, F.B., Olabiyi, A.A., Schmatz, R., Gutierres, J.M., Stefanello, N., Zanini, D., Rosa, M.M., Andrade, C.M., Rubin, M.A., Schetinger, M.R., Morsch, V.M., Danesi, C.C. and Lopes, S.T. (2016): Neuroprotective effects of quercetin on memory and anxiogenic-like behavior in diabetic rats: Role of ectonucleotidases and acetylcholinesterase activities. Biomed Pharmacother., 84:559-568.

37. Mbikay, M., Sirois, F., Simoes, S., Mayne, J. and Chrétien, M. (2014): Quercetin-3glucoside increases low-density lipoprotein receptor (LDLR) expression, attenuates proprotein convertase subtilisin/kexin 9 (PCSK9) secretion, and stimulates LDL uptake by Huh7 human hepatocytes in culture. FEBS open bio., 4: 755-62.

38. Milenković, M., Arsenović-Ranin, N., StojićVukanić, Z., Bufan, B., Vučićević, D. and
Jančić, I. (2010): Quercetin ameliorates experimental autoimmune myocarditis in rats. $\mathbf{J}$ Pharm Pharm Sci., 13(3): 311-319.

39. Moon, J., Lee, S.M., Do, H.J., Cho, Y., Chung, J.H. and Shin, M.J. (2012): Quercetin up-regulates LDL receptor expression in HepG2 cells. Phytother Res., 26(11): 16881694.

40. Nabavi, S.F., Moghaddam, A.H., Nabavi, S.M. and Eslami, S. (2011): Protective effect of curcumin and quercetin on thyroid function in sodium fluoride intoxicated rats. Fluorid., 44(3): 147-152.

41. Nanda, N., Bobby, Z. and Hamide, A. (2008): Association of thyroid stimulating hormone and coronary lipid risk factors with lipid peroxidation in hypothyroidism. Clin Chem Lab Med., 46:674 9.

42. Olayinka, E.T., Ore, A., Adeyemo, O.A., Ola, O.S., Olotu, O.O. and Echebiri, R.C. (2015): Quercetin, a flavonoid antioxidant, ameliorated procarbazine-induced oxidative damage to murine tissues. Antioxidants., 4(2): 304-321.

43. Roslan, J., Giribabu, N., Karim, K. and Salleh, N. (2017): Quercetin ameliorates oxidative stress, inflammation and apoptosis in the heart of streptozotocin-nicotinamideinduced adult male diabetic rats. Biomed Pharmacother., 86: 570-582.

44. Ruiz, L.M., Salazar, C., Jensen, E., Ruiz, P.A., Tiznado, W., Quintanilla, R.A. and Elorza, A.A. (2015): Quercetin affects erythropoiesis and heart mitochondrial function in mice. Oxid Med Cell Longev., 2015,836301

45. Sangeeta N., Singh Y.A., Devi O.P., Singh R.K.R., Chubalemla L., Abhishek D., Basar G., Ibahunlang R., Devi N.O. and Singh M.A. (2016): Lipid Profile in Thyroid Dysfunction Patients. IOSR-JDMS., 15 (12): $39-43$

46. Santi, A., Duarte, M.M., Moresco, R.N., Menezes, C., Bagatini, M.D., Schetinger, M.R. and Loro, V.L. (2010): Association between thyroid hormones, lipids and oxidative stress biomarkers in overt hypothyroidism. Clin Chem Lab Med., 48 (11):1635-1639. 


\section{FATMA M. LEBDA et al.}

47. Santi, A., Duarte, M.M., de Menezes, C.C. and Loro, V.L. (2012): Association of lipids with oxidative stress biomarkers in subclinical hypothyroidism. Int J Endocrinol., 2012.

48. Shashi, A. and Sharma, N. (2012): Lipid profile abnormalities in hypothyroidism. Int J Sci Nat., 3: 354-60.

49. Sherif, I.O. (2018): The effect of natural antioxidants in cyclophosphamide-induced hepatotoxicity: Role of Nrf2/HO-1 pathway. Int Immunopharmacol., 61: 29-36.

50. Tagami, T., Tamanaha, T., Shimazu, S., Honda, K., Nanba, K., Nomura, H. and Naruse, M. (2010): Lipid profiles in the untreated patients with Hashimoto thyroiditis and the effects of thyroxine treatment on subclinical hypothyroidism with Hashimoto thyroiditis. Endocr J., 57(3): 253-258.

51. Talirevic, E. and Jelena S. (2012): Quercetin in the treatment of dyslipidemia. Med Arh., 66(2):87-88.

52. Tangvarasittichai, S. (2015): Oxidative stress, insulin resistance, dyslipidemia and type 2 diabetes mellitus. World J Diabetes., 6(3): 456480.
53. Ting, Y., Chang, W.T., Shiau, D.K., Chou, P.H., Wu, M.F. and Hsu, C.L. (2018): Antiobesity efficacy of quercetin-rich supplement on diet-induced obese rats: effects on body composition, serum lipid profile, and gene expression. J Agric food chem., 66(1):7080.

54. Vijayakumar, K., Rengarajan, R.L., Radhakrishnan, R. and Anand, A.V. (2018): Hypolipidemic effect of Psidium guajava Leaf extract against hepatotoxicity in rats. Pharmacogn Mag., 14(53): 4-8.

55. Yan, S.X., Li, X., Sun, C.D. and Chen, K.S. (2015): Hypoglycemic and hypolipidemic effects of quercetin and its glycosides. Zhongguo Zhong Yao Za Zhi., 40 (23): 45604567.

56. Zhou, J., Cheng, G., Pang, H., Liu, Q. and Liu, Y. (2018): The effect of 131I-induced hypothyroidism on the levels of nitric oxide (NO), interleukin 6 (IL-6), tumor necrosis factor alpha (TNF- $\alpha$ ), total nitric oxide synthase (NOS) activity, and expression of NOS isoforms in rats. Bosn J Basic Med Sci., 10:17305-2350. 


\section{تأثثير مادة الكيرسيتين على مستوى الدهون و مؤشر ات}

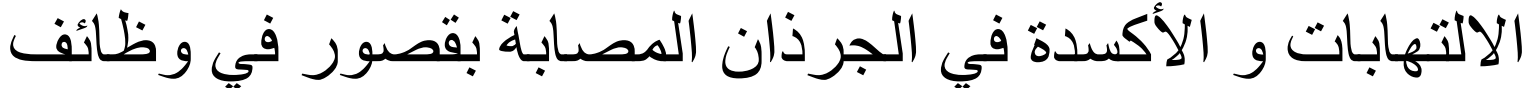

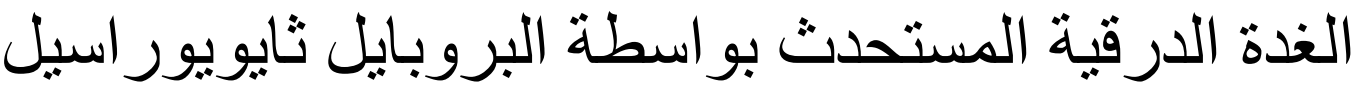

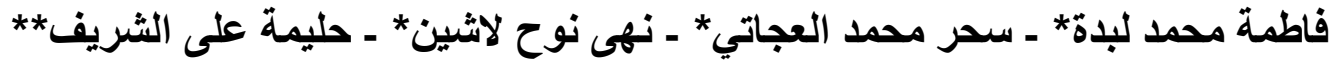

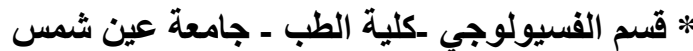

** قسم الفسيولوجي-كلية الطب جامعة المرقب_الخمس لئيبيا

خلفية البحث : قصور الغدة الدرقية هو اضطر اب منتشر له آثار ضارة مثل عسر في شحميات الدم ،

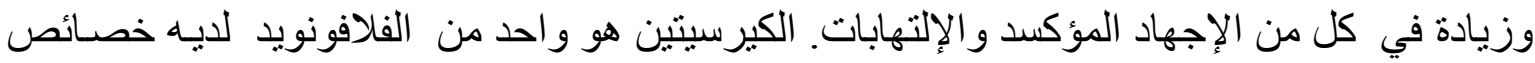
بيولوجية نافعة منها، مضادات الأكسدة ومكافحة الإلتهابات ، فضلا عن القدرة على منع تأكسد الدهون. الهـف مـن البحث: أجري هذا البحث لدراسـة التأثير النـافع و المحتمل للمعالجة بالكرسيتين على مستوى الدهون و دلالات الإجهاد المؤكسد و مؤشـرات الالتهابـات في جرذان التجـارب المصـابة بقصور في الغدة الدرقية بو اسطة البروبايل ثايويور اسيل.

مواد وطرق البحث: أجريت هذه الدراسـة على 0؛ مـ إنـاث الجرذان البالغة و التي تم تقسيمها عشو ائياً إلى المجموعات التالية : (كل مجموعة بها 10 جرذذ): مجموعة ضابطة و مجمو عة معالجة الجة بالبروبايل ثايو يور اسيل و مجمو عة معالجة بالبروبايل ثايويور اسيل و الكيرسيتين. و قد تعرضت كل الجرذان للقباسات التالية: وزن الجسم و مستوى هرمونات الغدة الدرقية في المصل و مستوى الدهون في البلازماو دلالات الإجهاد المؤكسد في البلازما (المالوندالدهيد والإنزيم المضاد للاككسة) و مؤشر الثران

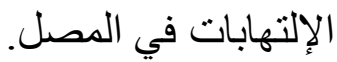

النتائج: و قد أظهرت النتائج إنخفاض في مستويات هرمونات الغدة الدرقية مصحوباً بزيادة ذات دلالة إحصائية في وزن الجسم النهائي و النسبة المئوية لوزن الجسم المكتسب و عسر في شحميات الدم

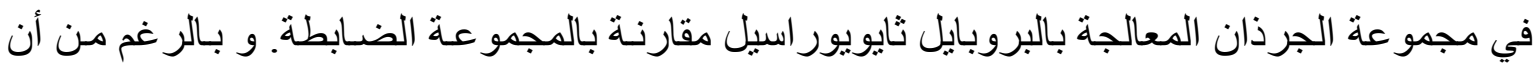

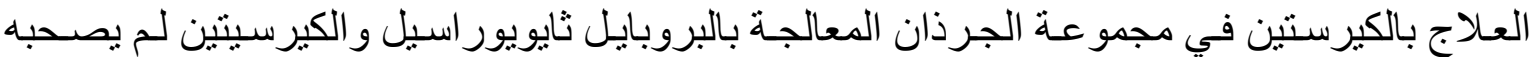
تحسن في مستويات هرمونات الغدة الدرقية إلا أنه أدى إلى نقص ذو دلالية إحصائية في كل من وزن الجسم النهائي و النسبة المئوية لوزن الجسم المكتسب مقارنة بمجموعة الجرذان المعالجة بالبروبايل

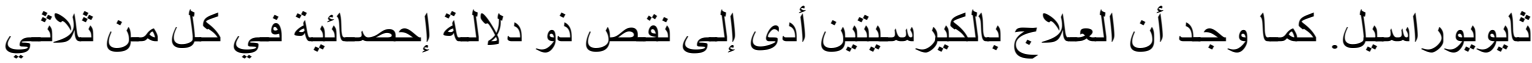
الجلسريد و الكوليستيرول الكلي و الكوليستيرول منخفض الكثافة مصحوباً بزيادة في الكوليستيرول عالي الكثافة ممـا أدى إلى تحسن ملحوظ في عسر شـميات الدم في مجموعـة الجرذان المعالجـة 


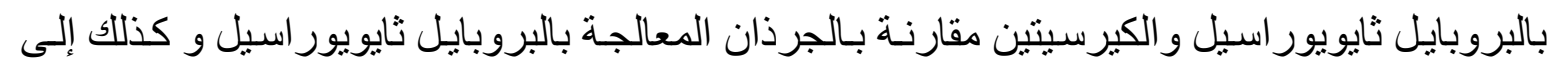

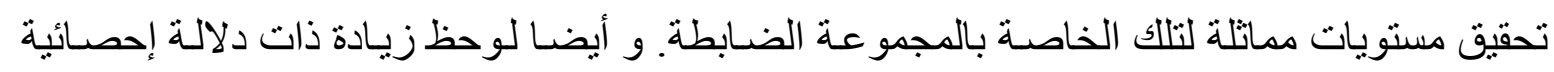

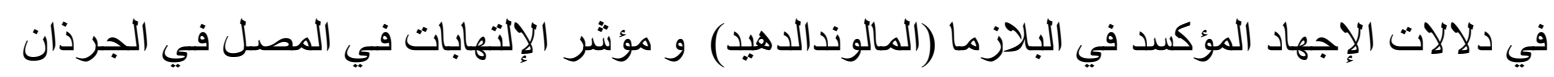

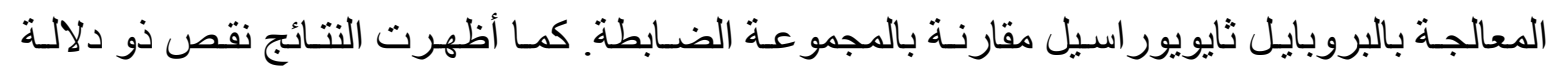

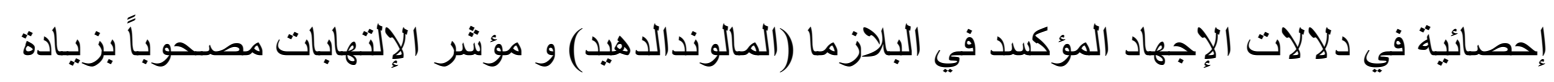

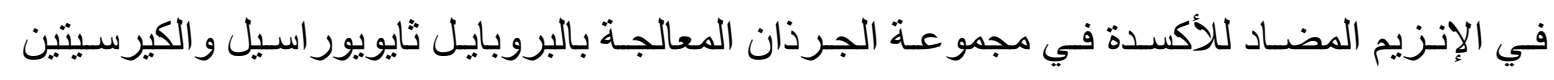

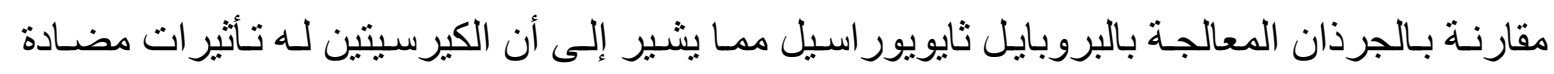
للأكسدة و مضادة للإلتهابات في الجرذان المصابة بقصور في الغدة الدرقية. الاستنتاج: ويستتتج من نتائج هذه الدر اسة إلى وجود تأثير وقائي و اضح للعلاج بالكيرسيتين ضد كل

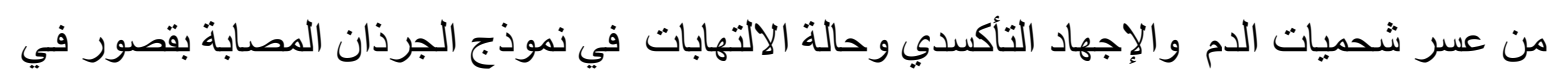

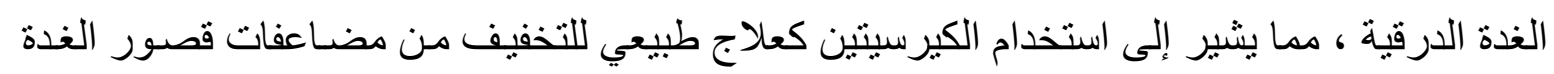

